\title{
French science under a benign bureaucracy
}

\section{Robert Fox}

SiNCE the 1660s, when Colbert first perceived that the act of patronizing the nation's savants might add to the lustre of the Sun King, French science has depended on the support of government to a degree unmatched elsewhere in Europe. The state of dependence has on occasions shown its darker side: in the 1850s, for example, Napoleon III's Ministry of Public Instruction was a byword for parsimony and for incomprehension of the true needs of scientific research. But, in general, the story has been otherwise, with scientists (in search of funds and public authority) and statesmen (in search of national prestige and technical expertise) finding a community of interest unknown in other realms of intellectual life.

The community of interest was never more evident than in the period treated in Professor Gillispie's learned and absorbing book. That, at least, is the implication of his meticulously detailed account of the main institutions and personalities of French science in the 15 years that separated the beginning of Turgot's ministry in $\mathbf{1 7 7 4}$ from the Revolution. By then, the Enlightenment, as we normally define it, was virtually over; yet enlightened spirits survived in the administration, working not at criticism and abstract prescription (in the manner of the Encyclopaedists) but at the practical business of rationalization and reform. In their task, modern-minded political leaders from Turgot to Breteuil looked to men of science to advise on the production of gunpowder and munitions, to improve public health and agriculture, to man the state-owned manufacturing enterprises at Sèvres and the Gobelins, and to serve as (and in turn to train) engineers in the various state corps, both civil and military. In the process, they not only brought together the worlds of science and polity but also, and even more importantly for Gillispie, caused an unprecedented expansion of the institutional provision for scientific work and education.

Gillispie's interpretation rests on a belief that the state's involvement was almost invariably benign. He shows how scientists and engineers of the stature of Lavoisier, Berthollet, Vicq d'Azyr, Monge and Coulomb, all of whom benefited from the new possibilities of career-making, were glad to assume the mantle of public servants, seemingly untroubled by any thought that such roles might conflict with their quest for a scientific reputation or damagingly reduce their freedom. The analysis of Science and Polity makes good sense of this compliance. For the accolade of official recognition and the opportunity
Science and Polity in France at the End of the Old Regime. By Charles Coulston Gillispie. Pp.601. ISBN0-691-08233-2. (Princeton University Press: 1981). \$52.50, $£ 28.20$.

of appearing as the benefactors of society gave welcome substance to the scientists' claims to professional status. It is no wonder, therefore, that the state was regarded as the benevolent partner of the scientific community, while the enemies of science were identified elsewhere, in the world of the charlatans on the shady fringes of respectability. The very fact that certain pretenders to scientific competence were instantly recognized as threats is the surest touchstone of an incipient professional self-consciousness which united the Academy of Science in its opposition to Mesmer's notions of animal magnetism and in its frosty disregard of the physicist and future regicide, Marat. At the time, there could have been no conception of the age of the professional academic that was to dawn in the nineteenth century. But the possession of esoteric natural knowledge was already seen as a bond which distinguished such diverse groups as doctors, engineers, astronomers and industrial chemists from the rest of society, not least from the cultivated men of letters. Increasingly, and quite irrevocably by the time of the Revolution, it set the trained technical expert apart from, and in his own view above, those encyclopaedic generalists who had embodied enlightenment only 30 years before.

Readers of this book who know Professor Gillispie's earlier writings will recognize in it some of his favoured themes. His conviction of the nobility of the scientific enterprise is undimmed, though his handling of the quacks, Mesmer and Marat, is restrained and sensitive; his preference for doers rather than the layers of plans and the writers of manifestos is evident in his admiration for Turgot and (presumably) in the meagre space allotted to the wordy and ineffectual idéologues. Above all, there is scholarship as thorough as ever, and a knowledge of French ways and a love of France without which no Anglo-Saxon could ever have embarked upon such a formidable task. As a comprehensive work of reference on the official face of French science in the 1770s and $1780 \mathrm{~s}$, it is hard to imagine that Science and Polity will ever have its equal. There is still, of course, ample room for studies of the unofficial, voluntarist tradition, perhaps with a focus on the provincial academies or on private scholars and the teachers in the provincial collèges and universities. But the real meat of French science in the later eighteenth century is undoubtedly in these 600 closely printed pages.

Professor Gillispie's friends and classes of grateful pupils at Princeton have had occasion to know that this book has been long in the writing - inevitably so, for in both conception and execution it is a work on the grand scale. I can pay it no greater compliment than to say that the wait has been well worth while.

Robert Fox is Reader in the History of Science at the University of Lancaster and President of the British Society for the History of Science. His most recent book, co-edited with George Weisz is The Organization of Science and Technology in France, 1808-1914 (Cambridge University Press, 1980).

\section{Hoyle on ice}

\section{G. de Q. Robin}

Ice: How the Next Ice Age Will Come and How We Can Prevent It. By Fred Hoyle. Pp.191. ISBN 0-09-145320-8. (Hutchinson: 1981.) £7.95.

IN my research-student days, a colleague with literary ambitions threw his draft thesis on nuclear physics out of the window and settled down to write real fiction instead, although without much success. Fred Hoyle, in contrast, has succeeded in producing outstanding work in both astrophysics and science fiction.

The reader of Ice may well ask whether this is a serious scientific study or a piece of science fiction. Although ostensibly written as the former, the answer is not entirely clear. Basic scientific concepts are described to the layman with considerable skill, but more emphasis appears to be given to the dramatic idea than to a balanced scientific assessment.

Hoyle reviews a wide range of evidence on ice ages, taken from biological as well as physical sciences. The disappearance of biological species over short periods and geological evidence convinced him that climatic changes such as the onset and ending of ice ages take place suddenly. This leads to the hypothesis that ice ages are started by the impact of vast stony meteorites (of the order of $1 \mathrm{~km}$ in diameter) and ended by impact of similar iron meteorites. The dust from the first impact shrouds the Earth so effectively for a decade that the surface is cooled rapidly, leading to the formation of extensive ice cover over land and chilling of the warm 